\title{
ENRICHMENT OPAK KELOR IKAN MODIFIKASI DAN DAMPAKNYA PADA ANAK STUNTING DI KABUPATEN LOMBOK UTARA
}

\author{
Fifi Luthfiyah ${ }^{1^{*}}$ dan Susilo Wirawan ${ }^{1}$ \\ ${ }^{1}$ Jurusan Gizi, Poltekkes Kemenkes Mataram, Indonesia \\ Jalan Praburangkasari Dasan Cermen, Sandubaya Kota Mataram \\ Email : lutfi_tyo@yahoo.co.id
}

\begin{tabular}{l} 
Article Info \\
Article history: \\
Received January $2^{\text {th }}, 2020$ \\
Revised February $5^{\text {th }}, 2020$ \\
Accepted March $30^{\text {th }}, 2020$ \\
\hline
\end{tabular}

Kata Kunci :

Anak Stunting; Enrichment; OKI Modifikasi.

\begin{abstract}
Stunting prevalence (5-12 years) is $34.4 \%$ which is the highest number in the NTB region compared to 10 other regencies / cities (NTB Province average of 14.9\%) (Riskesdas, 2013). Fish Kelor Opak (OKI) is one of the traditional foods that can be strived to reduce Stunting (very short) in nutrient-prone groups in North Lombok Regency. In the three years of Health Intervention Research, problems still arise that quite disturb the sustainability of OKI consumption. There are not yet many traditional Opak craftsmen who produce Fish Kelor Opac (OKI) because of the ability of the craftsmen to provide raw materials and need modification of the materials, so that people like it. The purpose of this study was to modify Fish Moringa Opaque and its effects on stunting children. Descriptive observational method with emphasis on making Moringa Fish Opaque with different fish ingredients. The best products are given to children stunting. The results showed that modified Fish Opaque Moringa was made which had better taste, shape and texture than before. There is a difference in $B B$ in children with stunting + $O K I(P 1)$ before and intervention is $2.07 \mathrm{~kg}$, compared to $P 0$ of 0.56 $\mathrm{kg}$ and There is a difference in TB in children with stunting $+O K I$ (P1) before and after the intervention of $0.54 \mathrm{~cm}$ compared to $P 0$ of $0.4 \mathrm{~cm}$.
\end{abstract}

\footnotetext{
ABSTRAK

Angka prevalensi stunting (5-12 tahun) yaitu 34,4\% yang merupakan angka tertinggi di wilayah NTB dibandingkan 10 Kabupaten/Kota lainnya (Rata-rata Propinsi NTB 14,9\%) (Riskesdas,2013). Opak Kelor Ikan (OKI) menjadi salah satu jenis makanan tradisional yang dapat diupayakan untuk menurunkan Stunting (sangat pendek) pada kelompok rawan gizi di Kabupaten Lombok Utara. Dalam tiga tahun Riset Intervensi Kesehatan masih timbul permasalahan yang cukup mengganggu keberlanjutan konsumsi OKI. Belum banyaknya pengrajin Opak tradisional yang memproduksi Opak Kelor Ikan (OKI) karena kemampuan pengrajin menyediakan bahan baku dan perlu modifikasi dari bahan, sehingga masyarakat menyukainya. Tujuan penelitian ini adalah melakukan modifikasi Opak Kelor Ikan serta efeknya pada anak stunting. Metode observasional deskriptif dengan menitikberatkan pada pembuatan Opak Kelor Ikan dengan bahan ikan yang berbeda. Produk terbaik diberikan kepada anak stunting. Hasil penelitian menunjukkan Opak Kelor Ikan modifikasi telah dibuat yang memiliki rasa, bentuk dan tekstur lebih baik dari sebelumnya. Terdapat perbedaan BB pd klp anak stunting $+O K I(P 1)$ seblum dan stlah intervensi $2,07 \mathrm{~kg}$, dibanding $P 0$ sebesar $0,56 \mathrm{~kg}$ dan Terdapat perbedaan TB pd klp anak stunting $+O K I(P 1)$ sebelum
} 
dan setelah intervensi sebesar 0,54 cm dibandingkan P0 sebesar 0,4 $\mathrm{cm}$.

Copyright $($ ) Jurnal Gizi Prima All rights reserved.

\section{PENDAHULUAN}

$\begin{array}{r}\text { Copyright } \odot \text { Jurnal Gizi Prima } \\ \text { All rights reserved. } \\ \hline\end{array}$

Angka prevalensi Stunting (5-12 tahun) yaitu 34,4\% yang merupakan angka tertinggi di wilayah NTB dibandingkan 10 Kabupaten/Kota lainnya (Rata-rata Propinsi NTB 14,9\%) (Riskesdas 2013). Hasil penelitian Opak Kelor Ikan (OKI) yang dilakukan oleh Susilo, dkk dan Luthfiyah, F,(Wirawan and Luthfiyah 2015)(Luthfiyah and Widjajanto 2016)menunjukkan bahwa salah satu pangan lokal yang ada di Kabupaten Lombok Utara adalah "opak-opak" yang berbahan dasar dari singkong dan telah diperkaya dengan kelor dan ikan untuk meningkatkan nilai gizinya.

Masyarakat Lombok Utara sangat mengenal dan menggemari opak-opak. Menurut mereka keuntungan mengonsumsi opak-opak antara lain, enak, mengenyangkan, harganya murah dan mudah untuk mendapatkannya. Selain anak-anak, remaja, dewasa dan orang tua baik laki-laki maupun perempuan sangat menggemari opak-opak. Mereka yang tidak sempat makan pagi kadang kala hanya mengonsumsi dua keping opak-opak ditambah mihun atau pelecing di atasnya sudah dapat mengatasi rasa lapar.(Thamrin et al. 2013).

Opak-opak yang asli terbuat dari bahan singkong segar yang diparut dan dibiarkan semalam agar terbentuk endapan pati di bawahnya.(Wirawan and Luthfiyah 2015) Selanjutnya dengan menambahkan parutan kelapa, hasil endapan pati tersebut dicampur hingga rata juga menambahkannya dengan air dan garam secukupnya. Hasil akhir dari adonan tersebut adalah suatu emulsi atau adonan yang cukup kental yang dapat dicetak berbentuk lingkaran dengan diameter $15-20 \mathrm{~cm}$. Selanjutnya adonan siap dicetak dengan cara menuangkan 1 sendok sayur ukuran sedang ke dalam wajan anti lengket sehingga membentuk lingkaran.

Opak tradisional tersebut telah diperkaya dengan serbuk daun kelor dan ikan ekor kuning (OKI) untuk meningkatkan nilai gizinya. Nilai gizi OKI dalam $100 \mathrm{~g}$ adalah energi : 382,97 kkal, Karbohidrat 83,9 g, Protein : 2,64 g, Lemak : 4,07 g. (Hasil analisis proksimat di UB dan UGM, 2014) Opak Kelor Ikan tersebut telah diterima dan mulai populer di masyarakat Kabupaten Lombok Utara (Kecamatan Pemenang, Tanjung dan Gangga). (Wirawan and Luthfiyah 2015)

Dalam tiga tahun Riset Intervensi Kesehatan masih timbul permasalahan yang cukup mengganggu keberlanjutan konsumsi OKI. Permasalah tersebut antara lain belum banyaknya pengrajin Opak tradisional yang memproduksi Opak Kelor Ikan (OKI) hal ini tentu berhubungan langsung dengan kemampuan pengrajin menyediakan bahan baku. Perlu dilakukan upaya agar Opak Kelor Ikan (OKI) dapat diterima dan makin meluas dikenal di masyarakat

\section{METODE PENELITIAN}

Desain penelitian ini menggunakan desain observasional deskriptif pada pembuatan Opak Kelor Ikan modifikasi dan dengan pendekatan pre eksperimen penelitian pre and post test randomized group design untuk membuktikan efeknya pada anak stunting. Populasi adalah seluruh Anak Sekolah Dasar kelas 3 s.d. kelas 5 di Wil. Kec. Pemenang dan Kec. Tanjung di Kab. Lombok Utar, sedangkan sampel adalah Kelompok yang akan diintervensi (p1) dan kelompok kontrol (P0) dan setiap anak mendapat 4 keping OKI selama 43 hari.

\section{HASIL PENELITIAN}

Opak kelor ikan modifikasi

Pembuatan OKI (Opak Kelor Ikan) modifikasi telah dilakukan di 2 pengerajin atau produsen opak. Opak kelor ikan modifikasi yang dibuat telah mengalami perkembangan, terutama dari segi metode pembuatan, rasa, dan bentuk. Metode Pembuatan Pembuatan OKI modifikasi berbeda dengan OKI yang sebelumnya dari segi metode yaitu bahan sagu baik baik dari tepung tapioka atau dari sari pati ubi dicampur dengan daun kelor segar dan ikan yang tidak dikukus (ikan segar), hal ini mempengaruhi tekstur dan warna . teksturnya menjadi lebih cerah, rasanya lebih gurih, dan aroma ikan lebih tajam. Rasa. Pembuatan OKI modifikasi yang menggunakan teknik pencampuran yang berbeda tersebut menimbulkan inisiatif dari produsen untuk 
mencoba rasa yang lain, sehingga tercipta rasa opak udang, opak ebi, dan opak original. Semua jenis rasa tersebut diproduksi dan dicoba untuk dijual.

Tabel 1. Persepsi Konsumen Terhadap Opak Yang Diperkaya Kelor Dan Ikan Yang Diterima

\begin{tabular}{lccc}
\hline \multicolumn{1}{c}{ Variabel } & Katagori & Jumlah & Prosentase \\
\hline Rasa Opak (OKI) & Enak & 27 & 90 \\
& Kurang enak & 3 & 10 \\
& Tidak enak & 0 & 0 \\
Tingkat kepahitan Opak (OKI) & Jumlah & 30 & 100 \\
& Tidak pahit & 30 & 100 \\
& Agak pahit & 0 & 100 \\
Tekstur/kerenyahan Opak (OKI) & Pahit & 0 & 83 \\
& Jumlah & 30 & 17 \\
& Renyah & 25 & 100 \\
Ukuran Opak (OKI) & Kurang renyah & 5 & 10 \\
& Jumlah & 30 & 0 \\
& Besar & 3 & 90 \\
& Sedang & 0 & 100 \\
\hline
\end{tabular}

Berdasarkan tabel di atas dapat dilihat bahwa sebagian besar umur ibu balita sebagian besar pada rentang 2030 tahun yaitu sebanyak 20 orang $(83.33 \%)$. Karakteristik ibu dilihat dari pendidikan yaitu sebanyak 18 orang $(75.00 \%)$ ibu balita tidak sekolah. Pekerjaan ibu sebagian besar adalah petani berjumlah 22 orang (91.67).

\title{
Bentuk
}

Bentuk OKI modifikasi juga berbeda dengan OKI sebelumnya. Setelah mendapatkan ide-ide baru, produsen mencoba mengembangkan opak dengan bentuk mini (diameter $12 \mathrm{~cm}$ ) dengan cetakan Teflon diameter 12 $\mathrm{cm}$. Sehingga dengan opak mini ini dikenal di masyarakat setempat dengan nama "Opak Mini Panggang" aneka rasa.

\begin{abstract}
Alat yang digunakan
Pada pembuatan OKI modifikasi tidak lagi mencetak menggunakan wajan biasa, mereka tapi mereka menggunakan wajan Teflon anti lengket, sehingga tidak dibutuhkan minyak atau kemiri untuk mengoles wajan, hanya saja kerugian terletak pada kelabang (alat penjemur dari pelapah pisang) jadi mudah rusak karena alat tersebut menjadi lengket dan matang.
\end{abstract}

\section{Harga}

Penjualan opak mini dengan berbagai rasa telah dilakukan oleh produsen di Desa Terengan tengah. Selama penelitian sejak bulan September -November 2017 (6 minggu) telah dijual lebih dari 600 bugkus (1 minggu 100 bungkus). Harga penjualan setiap bungkus Rp 2000,- . Penjualan tiap minggu telah dilakukan. Produsen menjual kepada kepada masyarakat di lingkungan setempat (warung-warung pinggir jalan, perkantoran, dan sekolah). Hasil penjualan per minggu adalah sebagai berikut,Hasil penelitian Ella Salamah*, Mar'atun Rohmah Susanti, Sri Purwaningsih, 2007 Kerupuk opak ikan 6\% dengan kemasan terbuka memiliki kadar air yaitu $14,05 \%$, kadar abu 4,70 \%, protein 6,81\%, lemak antara 0,76\%, dan karbohidrat 73,90\%. Lebih disukai konsumen dibandingkan dengan kadar ikan yang lebih tinggi.

\section{Dampak OKI Modifikasi Pada BB Dan TB Anak Stunting(Intervensi OKI Selama 43 Hari)}

Dalam penelitian ini, sampel yang digunakan adalah kelompok rawan gizi yaitu anak SD kelas $3-5$ dan ibu hamil pada trimester I dan II masing-masing berjumlah 40orang yang berada di wilayah Kecamatan Tanjung dan Gangga. 
ISSN : 2656 - 2480 (Online)

ISSN : 2355 - 1364 (Print)

Tabel 2. Distribusi Sampel (Anak Sekolah) Intervensi Dan Kontrol Menurut Karakteristiknya

\begin{tabular}{|c|c|c|c|c|}
\hline \multirow{3}{*}{ Variabel } & \multicolumn{4}{|c|}{ Anak Sekolah } \\
\hline & \multicolumn{2}{|c|}{ P1 } & \multicolumn{2}{|c|}{ P0 } \\
\hline & $\mathbf{n}$ & $\%$ & $\mathbf{n}$ & $\%$ \\
\hline \multicolumn{5}{|l|}{ Umur (tahun) } \\
\hline 9 & 16 & 40 & 16 & 40 \\
\hline 10 & 14 & 35 & 14 & 35 \\
\hline 11 & 8 & 20 & 8 & 20 \\
\hline \multirow[t]{2}{*}{12} & 2 & 5 & 2 & 5 \\
\hline & 40 & 100 & 40 & 100 \\
\hline \multicolumn{5}{|l|}{ Jenis Kelamin } \\
\hline $\mathrm{L}$ & 17 & 42,5 & 16 & 40 \\
\hline \multirow[t]{2}{*}{$\mathrm{P}$} & 23 & 57,5 & 24 & 60 \\
\hline & 40 & 100 & 40 & 100 \\
\hline \multicolumn{5}{|l|}{ Kelas } \\
\hline 3 & 13 & 32,5 & 13 & 32,5 \\
\hline 4 & 15 & 37,5 & 15 & 37,5 \\
\hline \multirow[t]{2}{*}{5} & 12 & 30 & 12 & 30 \\
\hline & 40 & 100 & 40 & 100 \\
\hline \multicolumn{5}{|l|}{ Konsumsi } \\
\hline$<80 \% \mathrm{AKG}$ & 35 & 87,5 & 32 & 80 \\
\hline \multirow[t]{2}{*}{$80-100 \%$ AKG } & 5 & 12,5 & 8 & 20 \\
\hline & 40 & 100 & 40 & 100 \\
\hline \multicolumn{5}{|l|}{ Status Gizi (TB/U) } \\
\hline Pendek & 31 & 77,5 & 30 & 75 \\
\hline \multirow[t]{2}{*}{ Normal } & 9 & 22,5 & 10 & 25 \\
\hline & 40 & 100 & 40 & 100 \\
\hline
\end{tabular}

Keterangan :

$\mathrm{P} 1=$ Kelompok intervensi $=\mathrm{OKI}$

$\mathrm{P} 0=$ Kelompok kontrol = Opak Biasa

Perubahan Berat Badan dan Tinggi Badan

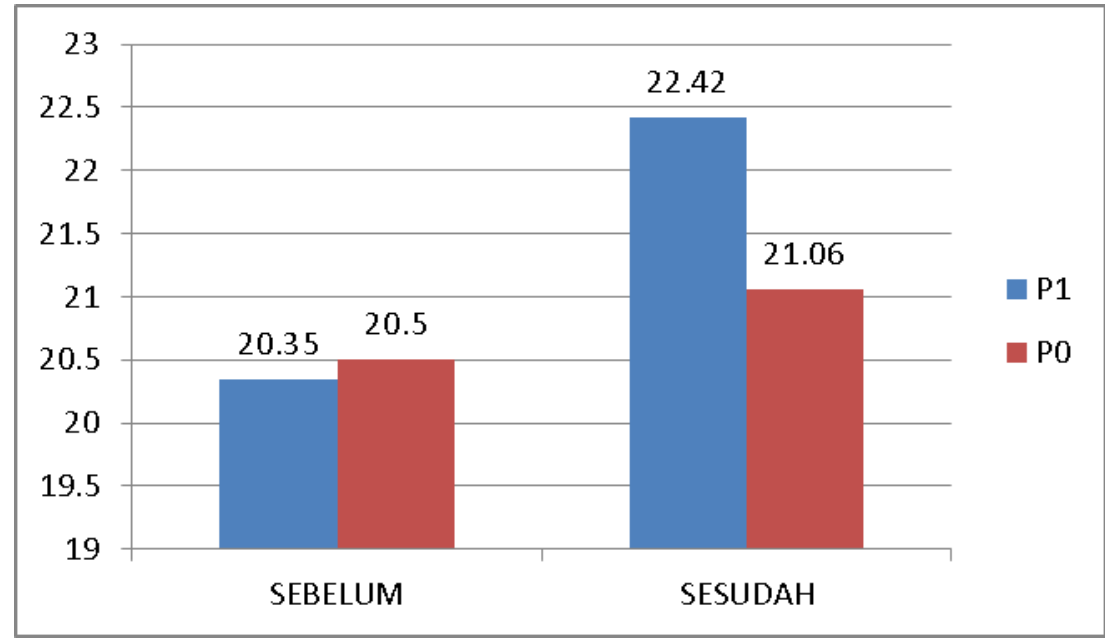

Grafik 1. Perubahan Berat Badan pd Kelompok P1 dan Po sebelum dan setelah intervensi 


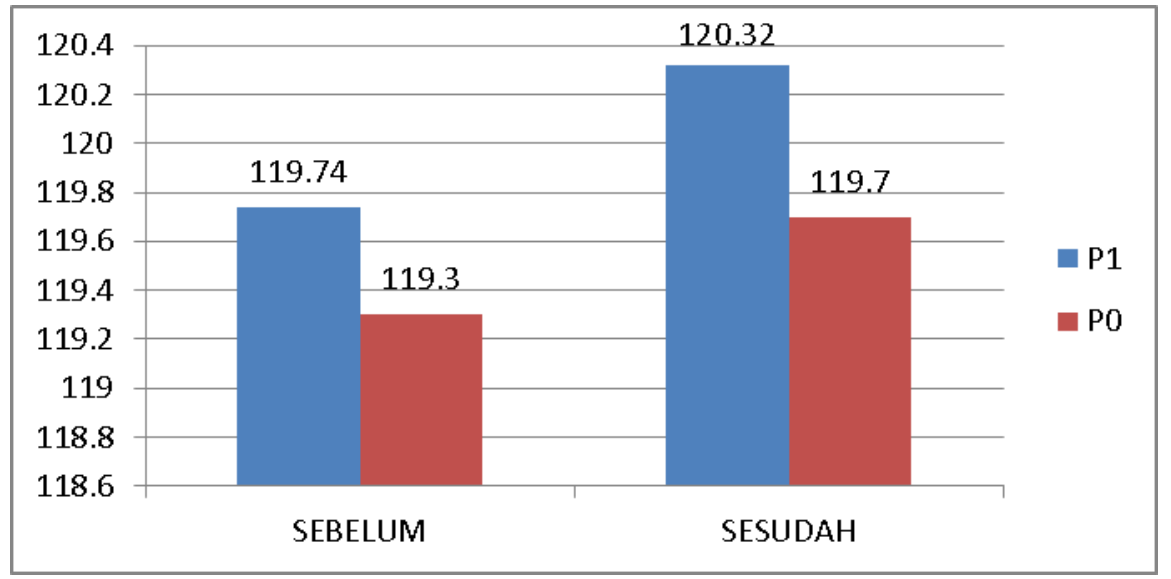

Grafik 2. Perbedaan TB sampel kelompok P1 dan P0 sebelum dan setelah intervensi

Terdapat perbedaan BB pd klp anak stunting+OKI (P1) seblum dan stlah intervensi 2,07 kg, dibanding P0 sebesar $0,56 \mathrm{~kg}$, dan terdapat perbedaan TB pd klp anak stunting+OKI (P1) sebelum dan setelah intervensi sebesar 0,54 cm dibandingkan P0 sebesar 0,4 cm.

\section{PEMBAHASAN}

\section{Produk Enrichment Opak Kelor Ikan Modifikasi}

Dalam membuat gerupuk tunu (Opak Kelor Ikan), singkong yang digunakan sebagai bahan dasar disiapkan terlebih dahulu. Jenis singkong yang baik digunakan adalah Singkong Manggu yang telah dikenal sejak lama dan mempunyai diameter batang $4-5 \mathrm{~cm}$. Jenis singkong yang satu ini bisa dikonsumsi karena mempunyai rasa yang enak, manis, dan dapat diolah menjadi beragam makanan. Penggunaan singkong segar dapat digantikan dengan sagu (tepung tapioka) dengan komposisi yang sudah ditentukan setara dengan singkong segar.(Luthfiyah 2012) Kelebihan penggunaan tepung tapioka adalah lebih putih, lebih krispi dan mudah mengembang. Ikan ekor kuning (Caesionidae) cukup populer di kalangan masyarakat Indonesia karena tekstur lembut dengan rasanya yang gurih dan lezat. Ikan laut yang hidup di perairan Indo Pasifik. Ikan ini disebut fusilier, suli, sulih, suliri, sunin.(Nisak et al. 2014)Tetapi karena keterbatasan ikan tersebut, pembuatan Opak Kelor Ikan Modifikasi menggunakan pengganti ikan ekor kuning yaitu ebi, udang dan cumi kering. Sehingga rasa yang diperoleh produk bervariasi dan disukai masyarakat. Menurut Simbolon (2008), kandungan gizi daun kelor segar dan daun kelor kering (serbuk) berbeda. Serbuk daun kelor memiliki nilai gizi yang lebih banyak daripada daun kelor segar. Protein serbuk kelor 27,1 gr setiap 100 gr-nya sedangkan daun kelor segar adalah 6,8 gram setiap 100 gr-nya.(Suriaman and Khasanah 2017) Keuntungan serbuk daun kelor lainnya adalah daya simpan yang relatif lebih lama daripada daun kelor segar. Penggunaan daun kelor pada produk OKI modifikasi dengan serbuk. Sehingga pencampuran dengan adonan lebih mudah dan lebih tahan lama. Diharapkan setalah dilakukan modifikasi produk OKI modifikasi terus diterima oleh masyarakat setempat dan pemerintah Kabupaten Lombok Utara memberikan dukungan kepada produsen opak untuk memproduksi OKI modifikasi secara bertahap.

\section{Dampak OKI Modifikasi pada Anak Stunting}

Asupan energi dan protein serta persen AKG dari konsumsi harian OKI dan OB (Opak Biasa) diketahui konsumsi opak biasa dan OKI kontrol memberikan rata-rata kontribusi energi tidak beda secara statistik $(p>0,05)$ dibandingkan dengan konsumsi opak biasa dan OKI perlakuan, tetapi untuk kontribusi energi terhadap AKG pada kelompok kontrol adalah lebih tinggi dan berbeda sangat nyata $(\mathrm{p}<0,01)$ dibandingkan dengan kelompok perlakuan. Rata-rata kontribusi protein juga tidak berbeda secara statistik $(p>0,05)$, tetapi kontribusi protein terhadap AKG pada kelompok perlakuan adalah lebih tinggi dan berbeda sangat nyata $(\mathrm{p}<0,01)$ dibandingkan dengan kelompok kontrol. Kecukupan gizi anak, selain dipengaruhi pemberian makanan tambahan OKI juga ditentukan oleh konsumsi pangan harian lainnya. Hasil uji t menunjukkan bahwa pada akhir dan awal intervensi dari konsumsi makanan harian pada anak yang mendapat perlakuan Opak biasa pada kelompok kontrol dan OKI (kelompok perlakuan) perbedaan sangat nyata $(\mathrm{p}<0,01)$ terhadap asupan dan tingkat kecukupan energi, dan protein menunjukkan perbedaan sa-ngat nyata $(\mathrm{p}<0,01)$. Hal ini menunjukkan bahwa konsumsi OKI pada kelompok intervensi (P1) selama intervensi dapat meningkatkan nafsu makan harian anak.(Thamrin et al. 2013) 
Secara garis besar penyebab stunting dapat dikelompokkan ke dalam tiga tingkatan yaitu tingkat masyarakat, rumah tangga (keluarga) dan individu. Pada tingkat rumah tangga (keluarga), kualitas dan kuantitas makanan yang idak memadai; tingkat pendapatan; pola asuh makan anak yang tidak memadai; pelayanan kesehatan dasar yang tidak memadai; sanitasi dan air bersih yang tidak memadai menjadi faktor penyebab stunting, dimana faktor-faktor ini terjadi akibat faktor pada tingkat masyarakat.

Konsekuensi defisiensi zat gizi makro selama masa anak-anak sangat berbahaya. Kekurangan protein murni pada stadium berat menyebabkan kwashiorkor pada anak-anak di bawah lima tahun. Kekurangan protein juga sering ditemukan secara bersamaan dengan kekurangan energi yang menyebabkan kondisi yang dinamakan marasmus . (Shiundu, Prof, and Oniang 2006)

Protein sendiri mempunyai banyak fungsi, di antaranya membentuk jaringan tubuh baru dalam masa pertumbuhan dan perkembangan tubuh, memelihara jaringan tubuh, memperbaiki serta mengganti jaringan yang rusak atau mati, menyediakan asam amino yang diperlukan untuk membentuk enzim pencernaan dan metabolisme. (Luthfiyah and Widjajanto 2016)(Leoni 2012)Defisiensi vitamin A mempengaruhi sintesis protein, sehingga akan mempengaruhi pertumbuhan sel. Karena itulah, maka anak yang menderita defisiensi vitamin A akan mengalami kegagalan pertumbuhan (Almatsier, 2005).

Studi Brown(2008) di Surabaya, menemukan bahwa di antara balita yang kadar retinol $<20 \mu \mathrm{g} / \mathrm{dl}$, ditemukan status gizi (TB/U) pendek sebesar 33,3 persen dan sangat pendek 26,7 persen.(WHO 2005)(Brown 2003) Sementara pada penelitian Suiraoka, dkk 2011 konsumsi protein dan zat gizi mikro lainnya pada anak stunting lebih sedikit daripada anak normal, dan frekuensi sakit pada balita stunting lebih tinggi 73,3\% dari yang normal.(Suiraoka I Putu, Kusumajaya AAN 2011)

\section{KESIMPULAN}

Telah dibuat Opak Kelor Ikan Modifikasi yang lebih baik dari segi warna, tekstur, rasa dan bentuknya. Aneka rasa dari Opak juga telah dihasilkan dan mendapat respon yang baik pada masyarakat. Intervensi Opak Kelor Ikanpada masyarakat khususnya Anak SD Stunting membuktikan perubahan Berat Badandan Tinggi Badanyang lebih besar dibandingkan dengan kelompok kontrol $(\mathrm{p}<0,001)$.

\section{DAFTAR PUSTAKA}

Brown, Kenneth H. 2003. "Symposium: Nutrition and Infection, Prologue and Progress Since 1968 Diarrhea and Malnutrition 1," 328-32.

Leoni, Astrine Permata. 2012. "Hubungan Umur, Asupan Protein, Dan Faktor Lainnya Dengan Kadar Gula Darah Puasa Pada Pegawai SATLANTAS Dan SUMDA Di POLRESTA Depok." Jakarta: Universitas Indonesia.

Luthfiyah, Fifi. 2012. "PENGARUH SERBUK DAUN KELOR LOKAL NUSA TENGGARA BARAT (NTB) PADA TIKUS KURANG GIZI (EVALUASI BERAT BADAN DAN KADAR ALBUMIN SERUM)." Media Bina Ilmiah 6: 42-50.

Luthfiyah, Fifi, and Eddy Widjajanto. 2016. "Serbuk Daun Kelor Memulihkan Kondisi Fisik Gizi Buruk Pada Tikus Model Kurang Energi Protein The Effect of Leaves Powder Moringa Oleifera in Physical Recovery of Protein Energy Malnutrition Rat Model.” Journal Medicine of Brawijaya 26 (3): 131-35.

Nisak, Aulia Nurun, Prodi Pendidikan Kedokteran, Fakultas Kedokteran, and Universitas Sebelas Maret. 2014. "Daun Kelor Dan Ikan Gabus Suplemen Sebagai Menstruasi Remaja Anemia." Journal of Nutrition Univ. Sebelas Maret Surakarta.

Riskesdas. 2013. "Riset Kesehatan Dasar Kementerian RI." Proceedings, Annual Meeting - Air Pollution Control Association 6. https://doi.org/1 Desember 2013.

Shiundu, Kennedy M, Hon Prof, and Ruth K Oniang. 2006. "Principles of Nutritional Assessment by Rosalind S . Gibson" 5 (2): 4-5. 
Suiraoka I Putu, Kusumajaya AAN, Larasati Nuki. 2011. "Perbedaan Konsumsi Energi, Protein Dan Vitamin A Dan Frekuensi Sakit Karena Infeksi Pada Anak Balita Stunting Dan Normal Di Wilayah Kerja Puskesmas Karangasem I."

Suriaman, Edi, and Solikhatul Khasanah. 2017. "SKRINING AKTIVITAS ANTIBAKTERI DAUN KELOR ( Moringa Oleifera ), DAUN BIDARA LAUT ( Strychnos Ligustrina Blume ), DAN AMOXICILIN TERHADAP BAKTERI PATOGEN Staphylococcus Aureus" 3 (1): 21-25.

Thamrin, Abdullah, Retno Sri Lestari, Rudy Hartono, Jurusan Gizi, and Politeknik Kesehatan Kemenkes. 2013. "FORMULASI PEMBUATAN MAKANAN TAMBAHAN UNTUK BALITA GIZI KURANG" XV (1): $1-6$.

WHO. 2005. PREVENTING CHRONIC DISEASE A VITAL INVESTMENT. World Health.

Wirawan, Susilo, and Fifi Luthfiyah. 2015. "KELOR SEBAGAI ALTERNATIF MAKANAN SELINGAN BERGIZI UNTUK IBU HAMIL KEK DI KABUPATEN LOMBOK UTARA , NTB ( Intervention The Giving of Food Tradisional Opak-Opak With Enrichment of the Yellow Tail Fish and Powder Leaves Moringa as an Food Alternative of Distr," 203-10. 